\title{
PENGARUH KUALITAS PELAYANANTERHADAP KEPUTUSAN PEMBELIAN KONSUMEN DI ALFAMART KOTA PALANGKA RAYA
}

\author{
M. Zainal Arifin dan Pikri Azhari \\ IAIN Palangka Raya
}

\begin{abstract}
Service quality gives encouragement to consumer to tie a good association with a company. Good service will give an impact to decision of consumer to buy and also to the company itself. A good service quality is very important to create a consumer's satisfaction, especially in direct proof, capability, attentiveness, and warrant of a consumer's satisfaction. According to that reasons, so the statement of the problem of this research is the influence of service quality to consumer's buying decision in Alfamart in Palangka Raya city. This research is using a quantitative approach with survey. A population of this research is consumer of Alfamart in Palangka Raya city. The sample that is taken for this research amounts to 96 respondents which is taken with random sampling. Furthermore, for prequalification test is using normality test with Kolmogorov smirnov and Q-Q plot. Data analysis method is using correlation of product moment and simple regression using SPSS 16. From this study, it is found that the quality of the service and consumer's buying decision in Alfamart in Palangka Raya city have strong relation according to the result of coefficient of product moment which amounts to 0,810 . It is also found the amount of sig that is 0,000 which means there are significant relation. Furthermore, test of simple regression shows the amount of determination of coefficient 0,656 which means the influence of service quality to the consumer's buying decision is $65,6 \%$. It is found also the amount of $t$ count which is 13,386 which is bigger than $t$ table, so it can be concluded that service quality has significant influence to consumer's buying decision.
\end{abstract}

Keywords: service quality, buying decision

\section{PENDAHULUAN}

\section{Latar Belakang Masalah}

Era globalisasi ini, kualitas dipandang sebagai salah satu alat untuk mencapai keunggulan kompetetif karena kualitas merupakan salah satu faktor utama menentukan pemilihan produk dan jasa bagi konsumen. Kepuasan konsumen akan tercapai apabila kualitas produk dan jasa yang diberikan sesuai kebutuhannya. Kualitas yang baik merupakan hal yang sangat penting dalam menciptakan kepuasan pelanggan, namun untuk memahami bagaimana mengevaluasi kualitas yang diterima oleh konsumen tidaklah mudah ${ }^{1}$.

Dunia bisnis pelayanan dan profit ibarat dua sisi mata uang yang tidak dapat dipisahkan. Pelayanan yang baik akan berpengaruh terhadap profit dan berkolerasi dengan hasil yang akan didapat sebuah perusahaan. Artinya, pelayanan yang baik akan menciptakan suasana yang berkesinambungan.Seiring pertumbuhan ekonomi yang semakin maju khususnya di kota-kota besar, telah terjadi perubahan diberbagai sektor termasuk di bidang produksi dan industri dan juga terjadi pergeseran gaya hidup dari tradisonal ke moderen, sehingga menciptakan perubahan pola belanja konsumen khususnya di kota-kota besar, bentuk usaha

\footnotetext{
1 http:// endyf.blogspot.com/ 2009/ 02/ analisis-kepuasan -nasabah-pada.html. (online tanggal 08-03-2017).
} 
yang mengalami perkembangan pesat adalah minimarket. Sekarang ini banyak bermunculan minimarket dengan berbagai fasilitas yang semakin lengkap.

Saat ini banyak bermunculan swalayan, minimarket atau toko-toko sejenisnya di kota palangka raya yang tidak hanya satu atau dua, tetapi ada beberapa minimarket Alfamart yang berjejer dengan jarak yang tidak begitu jauh. Hal ini sangat menguntungkan konsumen, karena konsumen tidak susah untuk mencari kebutuhan yang diinginkan. disini minimarket Alfamart yang ada di Kota Palangka Raya sangatlah strategis menempatkan lokasinya, sehingga memudahkan pelanggan untuk menjangkaunya. Berada di tengah-tengah keramaian kampus dan dikelilingi komplek perumahan memudahkan untuk pelanggan memenuhi kebutuhannya.Jadi, untuk memberikan kepuasan kepada pelanggan, menurut kotler pelayanan adalah setiap tindakan atau kegiatan yang dapat ditawarkan oleh satu pihak ke pihak lainnya, yang pada dasarnya tidak terwujud dan tidak mengakibatkan kepemilikan apapun.

Pelayanan merupakan prilaku produsen dalam rangka memenuhi kebutuhan dan keinginan konsumen demi tercapainya kepuasan pada konsumen itu sendiri.minimarket Alfamart harus mampu memberikan pelayanan yang pasti dapat memberikan kepuasan terhadap pelanggan dalam memenuhi kebutuhan pokoknya. Pelayanan yang baik meliputi pelayanan langsung dan tidak langsung. Pelayanan langsung yaitu berupa harga, kualittas produk, promosi dan lainnya. Sedangkan pelayanan tidak langsung yaitu berupa kenyamanan pelanggan saat belanja, kebersihan toko, kelayakan produk yang dijual, keamanan toko, serta fasilitas lain yang dapat dirasakan oleh pelanggan namun tidak secara langsung diperlihatkan kepada pelanggan.2

Berdasarkan latar belakang di atas makan titik fokus masalah dalam penelitian ini adalah Bagaimana pengaruh kualitas pelayanan terhadap keputusan pembelian konsumen di Alfamart di Kota Palangka Raya?

\section{Landasan Teori}

\section{Teori Jual Beli}

Jual beli atau perdagangan dalam Islam harus mengikuti aturan-aturan syari'ah agar tujuan yang sesungguhnya dari perdagangan itu dapat tercapai. Kesejahteraan manusia di duniawi dan kebahagian akhirat, tanpa mengikuti aturan syariah kegiatan perdaganggan akan membawa ketimpangan dalam kehidupan manusia. Menurut istilah bai atau jual beli artinya: pertukaran harta dengan ketentuan memiliki dan memberi kepemilikan.

Al-bai atau jual beli merupakan akad yang diperbolehkan. Hal ini berlandasan atas dalildalil yang terdapat dalalm Al-Qur'an, Al Hadits ataupun ijma ulama. Diantara dalil yang memperbolehkan praktek jual beli adalah Qs. An Nissa ayat 29. Artinya: hai orang-orang yang beriman, janganlah kamu memakan harta kamu diantara kamu dengan jalan yang batil, tetapi hendaklah dengan perniagaan berdasar kerelaan diantaranya. ${ }^{3}$

a. Rukun Dan Syarat Jual Beli

1) Rukun jual beli

Rukun yang terdapat dalam jual beli ada 3 yaitu:
a) Akad
b) Orang - orang yang berakad
c) Ma'kud alaih4

\footnotetext{
${ }^{2}$ http:/ / www.kembar.pro/ 2015/ 07/ strategi-pemasaran-dan-bauran-pemasaran.html. (online tanggal 05-04-2017).

${ }^{3}$ M. Ali Hasan, Berbagai Macam Transaksi Dalam Islam, h.116

${ }^{4}$ Hendi Suhendi, Fiqih Muamalah,h. 70
} 
2) Syarat jual beli

Syarat yang terdapat dalam akad jual beli ada 4 macam yang harus disempurnakan yaitu:
a) Syarat in'iqad
b) Syarat Nafadz
c) Syarat sah
d) Syarat luzum

b. Macam-macam Jual Beli

Jual beli dapat ditinjau dari berbagai segi yaitu:

1) Ditinjau dari segi hukumnya

2) Ditinjau dari segi benda yang dijadikan objek jual beli

3) Ditinjau dari segi pelaku akad jual beli

4) Jual beli ditinjau dari objek transaksi, akad jual beli

5) jual beli yang dilihat dari penentuan harganya, akad jual beli ${ }^{5}$

c. Khiar Dalam Jual Beli

Dalam jual beli menurut agama islam dibolehkan memilih apakah akan meneruskan jual beli atau akan membatalkan. Disebabkan terjadinya oleh sesuatu hal, terdapat 3 macam khiar yaitu:
1) Khiar Majelis
2) Khiar Syarat
3) Khiar Aib

\section{Teori Pelayanan}

Pelayanan adalah proses pemenuhan kebutuhan melalui aktivitas orang lain secara langsung dan menolong menyediakan segala apa yang diperlukan oleh orang lain seperti tamu dan pembeli. Menurut Kotler pelayanan adalah setiap tindakan atau kegiatan yang dapat ditawarkan oleh satu pihak kepada pihak lainnya, yang pada dasarnya tidak terwujud dan tidak mengakibatkan kepemilikan apapun. 6

Kualitas menurut ISO 9000, adalah" derajat yang dicapai oleh karakteristik yang bersatu padu dalam memenuhi persyaratan). Persyaratan dalam hal ini adalah kebutuhan atau harapan yang dinyatakan biasanya tersirat atau wajib). Jadi, kualitas sebagaimana yang di interpresentasikan ISO 9000 merupakan perpaduan antara sifat dan karakteristik yang menentukan sejauh mana keluaran dapat memenuhi persyaratan kebutuhan konsumen.konsumen yang menentukan dan menilai sampai seberapa jauh sifat dan karakteristik itu memenuhi kebutuhannya. ${ }^{7}$

Tujuan utama adalah memberikan pelayanan yang bermutu tinggi kepada konsumen jika tujuan ini terpenuhi dan tercapai, terjadilah hal-hal yang positif. Kualitas pelayanan mempunyai hubungan yang erat dengan pelanggan. Hal ini telah dikemukakan dalam penelitian Bloemer "Service Quality Is Positively Across Different Types Of Service Industries". Selain itu, Zeithaml juga mengemukakan terdapat hubungan yang erat diantara keseluruhan dimensi dari kualitas pelayanan dengan pelanggan dari beberapa perusahaan. ${ }^{8}$

a. Bukti langsung atau (Tangibles)

b. Keandalan atau (Reliability)

\footnotetext{
${ }^{5}$ Hendi Suhendi, Fiqih Muamalah,h. 75-82

${ }^{6}$ Lloyd Finch, Costumer Service Respresentative, Jakarta: ppm, h. 1-3.

${ }^{7}$ Rambat Lupiyoadi \& A. Hamdani, Manajemen Pemasaran Jasa, Edisi 2, h. 175.

${ }^{8}$ Fajar Laksana, Manajemen Pemasaran, h. 100
} 
c. Ketanggapan atau (Responsivenes)

d. Jaminan atau (Assurance)

e. Empati atau (Emphaty) ${ }^{9}$

Islam mengajarkan bila ingin memberikan hasil usaha baik berupa barang maupun pelayanan/jasa hendak memberikan yang berkualitas, jangan memberikan yang buruk atau tidak berkualitas kepada orang lain. Dalam ekonomi Islam, keputusan pilihan ini tidak dapat dilakukan semaunya saja, semua prilaku harus dipadu oleh Allah lewat Al-Qur'an dan hadits. Dijelaskan dalam surah Al-Maidah ayat 2: Artinya. "Dan tolong-menolonglah kamu dalam (mengerjakan) kebajikan dan takwa, dan jangan tolong-menolong dalam berbuat dosa dan pelanggaran. Dan bertakwalah kamu kepada Allah, sesungguhnya Allah amat berat siksa-Nya".

\section{Teori Pemasaran}

Pemasaran dapat didefinisikan sebagai hasil aktifitas bisnis yang mengarahkan arus barang dan jasa dari produsen ke konsumen dan mencakup pembelian, penjualan.America Marketing Association menyatakan bahwa pemasaran dapat diartikan sebagai pelaksana dunia usaha yang mengarahkan arus barang-barang dan jasa dari produsen ke konsumen atau pihak pemakai. Adapun Kotler memberikan definisi pemasaran sebagai sebuah proses dalam masyarakat yang dengan seorang atau sekelompok mendapatkan apa yang mereka butuhkan dan inginkan dengan cara menciptakan pemberian atau tukar menukar produk dan jasa dengan orang lain. ${ }^{10}$

Strategi pemasaran adalah kumpulan petunjuk dan kebijakan yang digunakan secara efektif untuk mencocokan program pemasaran (produk, harga, promosi dan distribusi) dengan peluang pasar guna mencapai sasaran usaha. ${ }^{11}$ Di masa ini pimpinan dan tenaga pemasaran dalam suatu perusahaan. Selain merencanakan strategi dalam setiap perencanaannya. Mereka melakukan penalaran yang lebih mantap dalam menetapkan pilihan dalam suatu strategi tertentu. Di dalam menetapkan strategi pemasaran yang akan dijalankan, suatu perusahaan harus melihat situasi dan kondisi pasar serta menilai kedudukan atau posisi perusahaan.

Islam terdapat 9 etika pemasaran, yang akan menjadi prinsip-prinsip bagi syariah dalam menjalankan fungsi-fungsi pemasaran, yaitu:

1) Memiliki kepribadian spiritual

2) Berprilaku baik dan simpatik

3) Berlaku adil dalam bisnis

4) Bersikap melayani dan rendah hati

5) Menepati janji dan tidak curang

6) Jujur dan terpercaya

7) Tidak suka berburuk sangka

8) Tidak suka menjelek-jelekan

9) Tidak melakukan sogok ${ }^{12}$

Keahlian lain yang perlu ditingkatkan pada karyawan yang bekerja di bidang customer service adalah kemampuan untuk beradaptasi. Setiap konsumen memiliki karakter yang berbeda-beda. Untuk dapat memberikan pelayanan yang optimal, karyawan dituntut untuk dapat beradaptasi terhadap konsumen secara fleksibel dan profesional. Keahlian komunikasi juga

\footnotetext{
${ }^{9}$ http:/ / thedarkancokullujaba.blogspot.com/ 2010/12/ kualitas-pelayanan-jasa.html.(online

10Ika yunia Fauzia, Etika Bisnis Islam, Jakarta: Kencana Prenandamedia Group, 2013, h. 4-5.

11Muhamad Ismail Yusanto, Muhamad Karebet Widjajakusuma, Menggagas Bisnis Islam, Jakarta: Gema Insani Press, 2003, h. 169.

${ }^{12}$ Hermawan Kartajaya \& Muhammad Syakir Sula, Syariah Marketing, Bandung: Mizan, 2006, h. 67-94
} 
merupakan salah satu keahlian yang perlu ditingkatkan untuk dapat memberikan pelayanan yang memuaskan.

Menurut Kotler hubungan kualitas pelayanan dengan konsumen maksudnya yang menyangkut pelayanan dan kinerja atau hasil yang dirasakan. Pada umumnya harapan pelanggan merupakan perkiraan atau keyakinan konsumen tentang apa yang akan diterimanya apabila ia membeli atau mengkonsumsi suatu produk baik barang maupun jasa, sedangkan kinerja atau hasil yang dirasakan merupakan persepsi pelanggan terhadap apa yang ia terima setelah mengkonsumsi produk yang ia beli. ${ }^{13}$

\section{Teori Produk}

Produk adalah merupakan hasil dari kegiatan produksi yang berujud barang.Variabel pertama dari pemasaran dan cukup penting dan yang mempengaruhi kepuasan konsumen. Karena produk merupakan suatu yang ditawarkan ke pasar untuk memenuhi kebutuhan dan keinginan konsumen. Struktur beberapa komponen keputusan pembelian konsumen terhadap suatu produk seperti berikut.

1) Keputusan tentang jenis produk.

2) Keputusan tentang produk.

3) Keputusan tentang merk.

4) Keputusan tentang jumlah produk.

5) Keputusan tentang waktu pembelian.

6) Keputusan tentang cara pembayaran.

Pembelian konsumen sangat dipengaruhi oleh karakteristik budaya, sosial, pribadi, dan psikologis. Biasanya pemasaran tidak dapat mengendalikan faktor-faktor semacam itu tetapi mereka harus mempertimbangkannya. ${ }^{14}$ Berikut factor-faktor yang mempengaruhi keputusan konsumen terhadap suatu produk.

1) Faktor budaya

2) Faktor sosial

3) Faktor pribadi

4) Faktor psikologis

Keputusan pembelian adalah Kejadian penting yang sering ditunggu para sales adalah keputusan pembelian membeli produk mereka. Keputusan itu merupakan titik akhir perjalanan upaya bisnis perusahaan mereka. Perjalanan itu dimulai dari pengumpulan dana, memproduksi atau mengadakan barang. ${ }^{15}$ Konsumen tidak selalu memulai lima tahap pembelian produk seluruhnya. Konsumen mungkin melewati atau membalik beberapa tahap, tahaptahap proses keputusan pembelian ada lima adalah sebagai berikut.

1) Pengenalan masalah

2) Pencarian informasi

3) Evaluasi alternatif

4) Keputusan pembelian

5) Prilaku pasca pembelian

\footnotetext{
13Fajar Laksana, Manajemen Pemasaran, h. 96

14Philip Kotler Dan Gary Armstrong, Prinsip-Prinsip Pemassaran Edisi 12 Jilid 1, Jakarta: Erlangga, 2008, H.159

15Philip Kotler Dan Gary Armstrong, Prinsip-Prinsip Pemassaran, h.173-176
} 


\section{METODE}

Penelitian ini menggunakan pendekatan penelitian kuantitatif. Metode pengumpulan data dalam penelitian ini berupa observasi dan angket. Teknik analisis data yang digunakan adalah regresi sederhana yang didahului dengan uji validitas dan reliabilitas instrumen, uji normalitas data dan reliabilitas, uji normalitas sebaran data, serta uji korelasi.

\section{HASIL PENELITIAN DAN PEMBAHASAN \\ Penyajian Data Variabel X dan Variabel Y}

Distribusi Frekuensi Jawaban Responden Terhadap Pengaruh Kualitas Pelayanan. hasil menunjukkan jawaban kuesioner yang diperoleh dari 96 responden. Tabel tabulasi data variabel X (pengaruh kualitas pelayanan) diketahui skor tertinggi sebesar 5.00 dan skor terendah 3.00 kemudian jumlah rata-rata variabel X adalah 375,2667. Dengan demikian, jumlah ratarata skor variabel $\mathrm{X}$ adalah 375,2667 dibagi dengan jumlah sampel 96 adalah sebesar 3.90. Data interval X yang didapatkan dari rata-rata jumlah yang ada di tabulasi data variabel X. Langkah selanjutnya menentukan distribusi kategori dari variabel X dengan jumlah total ratarata dibagi dengan jumlah responden yaitu sebesar 375,2667: 96=3,90. Dari hasil yang didapatkan sebesar 3,90 maka variabel X, kualitas pelayanan masuk dalam kategori sedang.

Tabulasi data variabel Y (keputusan pembelian konsumen) diketahui skor tertinggi sebesar 5.00 dan skor terendah 3.00, kemudian jumlah rata-rata variabel Y adalah 395 dengan demikian jumlah rata-rata skor variabel X adalah 395 dibagi dengan jumlah sampel 96 adalah sebesar 4,11. Data interval Y yang didapatkan dari rata-rata jumlah yang ada ditabulasi data variabel Y. Langkah selanjutnya menentukan distribusi kategori dari variabel Y dengan jumlah total rata-rata dibagi dengan jumlah responden, yaitu sebesar 395: 96=4,11. Dari hasil yang didapatkan sebesar 4,11 maka variabel Y, kualitas pelayanan masuk dalam kategori sedang.

\section{Uji Normalitas}

Uji normalitas dengan one-sample Kolmogorov-smirnov tes diperoleh nilai asymp. Sig. sebesar 0,834 yang mana nilai ini lebih besar dari 0,05 yang berarti Ho diterima atau data residual berdistribusi normal.

\section{Uji Hipotesis}

\section{Analisis Kolerasi Sederhana}

Berdasarkan Hasil analisis diketahui signifikansi antara variabel kualitas pelayanan (X) dan variabel keputusan pembelian (Y) adalah nilai signifikansi 0,000. Dari hasil perbandingan nilai sig adalah $(0,000 \leq 0,05)$, maka Ho ditolak dan Ha diterima, artinya signifikan. Hal ini menunjukkan bahwa adanya hubungan kualitas pelayanan terhadap keputusan pembelian konsumen. Nilai koefisien kolerasinya adalah 0,810 yang artinya termasuk dalam kategori tingkat hubungan antara variabel sangat kuat.

\section{Analisis Regresi Sederhana}

Besarnya nilai kolerasi atau hubungan $(\mathrm{R})$ yaitu sebesar 0,810 dan dijelaskan besaan persentase pengaruh variabel bebas terhadap variabel terikat yang disebut koefisien determinasi yang merupakan hasil dari pengkuadratan R. Dari tabel di atas diperoleh diterminasi $\left(R^{2}\right)$ sebesar 0,656 yang mengandung pengertian bahwa pengaruh variabel bebas (pelayanan) terhadap variabel terikat (keputusan) adalah sebesar 65,6\% sedangkan sisanya dipengaruhi oleh variabel yang lain. 
Pengaruh yang nyata (signifikan) variabel kualittas pelayanan (X) terhadap keputusan

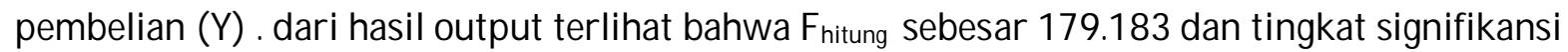
sebesar 0,000. Pada kolom B di baris constant (a) terdapat nilai 5,254 sedangkan pelayanan nilai sebesar 0,331 sehingga persamaan regresinya dapat ditulis sebagai berikut

$$
\begin{aligned}
& \mathbf{Y}=\mathbf{a}+\mathbf{b} \mathbf{X} \\
& Y=5.254+0,331 X
\end{aligned}
$$

Koefisien b dinamakan koefisien arah regresi dan menyatakan perubahan rata-rata variabel Y untuk setiap perubahan variabel X sebesar satu satuan. Perubahan ini merupakan pertambahan bila $\mathrm{b}$ bertanda positif dan penurunan bila $\mathrm{b}$ bertanda negatif sehingga dari persamaan tersebut dapat diterjemahkan sebagai berikut.

a) Konstanta sebesar 5.254 menyatakan bahwa jika tidak ada nilai pelayanan, maka nilai keputusan membeli sebesar 5.254.

b) Koefisien regresi $\mathrm{X}$ sebesar 0,331 menyatakan bahwa setiap penambahan 1 nilai pelayanan, maka nilai keputusan bertambah sebesar 331.

\section{Pembahasan}

Pelayanan ialah suatu kegiatan yang terjadi dalam interaksi langsung antara seseorang dengan orang lain dan memberikan kepuasan kepada konsumen. Dengan demikian, pelayanan adalah kegiatan yang dilakukan untuk memenuhi keinginan dan kebutuhan pihak lain. Pelayanan dapat juga disebut sebagai suatu tindakan yang dilakukan guna memenuhi keinginan konsumen akan suatu produk yang mereka butuhkan. Tindakan ini dilakukan untuk memberikan kepuasan kepada pelanggan berupa kemudahan, kecepatan, kemampuan dalam melayani konsumen dan keramahtamahan yang ditujukan melalui sikap dan sifat dalam memberikan pelayanan untuk kepuasan konsumen. Perusahaan menganggap konsumen adalah sebagai raja yang harus dilayani dengan baik, mengingat dari konsumen tersebut akan memberikan keuntungan kepada perusahaan agar dapat terus bersaing dengan perusahaan lainnya. Berdasarkan teori dari hasil penelitian menunjukkan bahwa antara variabel kualitas pelayanan dengan variabel keputusan pembelian konsumen memiliki pengaruh yang positif. Sehingga kualitas pelayanan menjadi salah satu faktor yang mempengaruhi keputusan pembelian konsumen di Alfamart Kota Palangka Raya. Dari hasil penelitian dengan kuesioner banyak dari responden yang menjawab baik.

Hasil analisis kolerasi sederhana (bivariate correlation) menunjukan bahwa nilai signifikansi 0,000 yang mana lebih kecil dari 0,05 yang artinya ada hubungan kedua veriabel, antara variabel kualitas pelayanan (X) dengan variabel keputusan pembelian (Y) dan nilai koefisien kolerasinya sebesar 0,810, artinya masuk dalam kategori memiliki hubungan antara variabel sangat kuat.

Penelitian juga telah menjelaskan bahwa dalam penelitian ini peneliti ingin mengetahui ada tidaknya pengaruh variabel (X) kualitas pelayanan Alfamart di Kota Palangka Raya terhadap variabel (Y) keputusan pembelian konsumen di Alfamart. Hasil analisis regresi sederhana menunjukan nilai koefisien determinasi $\left(\mathrm{R}^{2}\right)$ sebesar 0,656 yang mengandung pengertian bahwa pengaruh kualitas pelayanan variabel (X) terhadap keputusan pembelian variabel (Y) adalah sebesar 65,6\% sedangkan sisanya dipengaruhi oleh variabel yang lainnya.

\section{PENUTUP}

\section{Kesimpulan}

Penelitian ini bertujuan untuk mengetahui apakah ada tidaknya pengaruh kualitas pelayanan terhadap keputusan pembelian konsumen di Alfamart Kota Palangka Raya. Berdasar- 
kan hasil data yang diperoleh maupun hasil analisis yang telah dilakukan, dapat ditarik kesimpulan mengenai pengaruh kualitas pelayanan terhadap keputusan pembelian konsumen di Alfamart Kota Palangka Raya. Hasil analisis kolerasi sederhana (bivariate correlation) menunjukan bahwa nilai signifikansi 0,000 yang mana lebih kecil dari 0,05. Artinya, ada hubungan antara kualitas pelayanan variabel $(\mathrm{X})$ dengan keputusan pembelian variabel $(\mathrm{Y})$ dan nilai koefisien kolerasinya adalah sebesar 0,810 , artinya masuk dalam kategori memiliki hubungan antara variabel yang kuat. Hasil analisis regresi sederhana menunjukkan nilai koefisien determinasi ( $\left.\mathrm{R}^{2}\right)$ adalah sebesar 0,656 yang mengandung pengertian bahwa pengaruh variabel X terhadap variabel Y adalah sebesar 65,6\% sedangkan sisanya dipengaruhi oleh variabel yang lain.

\section{Saran}

Pihak Alfamart hendaknya memperhatikan kebersihan lingkungan dan memberikan fasilitas wifi sehingga mempengaruhi ketertarikan konsumen untuk melakukan pembelian di Alfamart. Karena semakin baik yang kita berikan dan semakin puas dengan apa yang mereka rasakan atas atribut-atribut yang diberikan akan berpengaruh terhadap keberlangsungan sebuah perusahaan.

\section{DAFTAR PUSTAKA}

Hasan M. Ali. 2003. Berbagai Macam Transaksi Dalam Islam. Jakarta: Rajawali Pers.

Hamdani, \& Rambat Lupiyoadi. Manajemen Pemasaran Jasa, Edisi 2.

Kotler Philip dan Gary Armstrong. 2008. Prinsip-Prinsip Pemassaran Edisi 12 Jilid 1. Jakarta: Erlangga.

Laksana, Fajar. 2008. Manajemen Pemasaran Pendekatan Praktis. Yogyakarta: Graha Ilmu.

Widjajakusuma, Muhamad Karebet dan Yusanto, Muhamad Ismail. 2003. Menggagas Bisnis Islam. Jakarta: Gema Insani Press.

Sula, Muhammad Syakir \& Kartajaya, Hermawan. 2006. Syariah Marketing. Bandung: Mizan.

Suhendi, Hendi. 2002. Fiqih Muamalah. Jakarta: Pt Raja Grafindo Persada.

Yunia, Fauzia Ika. 2013. Etika Bisnis Islam. Jakarta: Kencana Prenandamedia Group.

http:/ / endyf.blogspot.com/ 2009/ 02/ analisis-kepuasan-nasabah-pada.html. (Online Tanggal 08-03-2017).

http:/ / www.kembar.pro/ 2015/ 07/ strategi-pemasaran-dan-bauran-pemasaran.html. (Online Tanggal 05-04-2017).

http:/ / thedarkancokullujaba.blogspot.com/2010/12/ kualitas-pelayanan-jasa.html. （Online Tanggal 08-04-2017). 